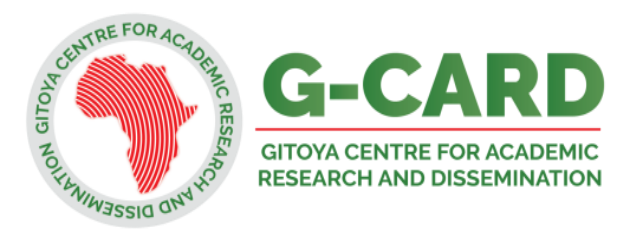

\title{
Influence of Psychosocial Guidance and Counselling Services on Secondary School Students' Academic Performance: A Case of Tanga City, Tanzania
}

\author{
Dorothy Lubawa ${ }^{1}$, Dr. Colletha Ngirwa ${ }^{2}$ and Dr. Theresia Shavega ${ }^{2}$ \\ ${ }^{1}$ University of Iringa, Tanzania \\ ${ }^{2}$ Open University of Tanzania \\ Corresponding Mail: dlubawa@yahoo.com
}

\begin{abstract}
This study examined the influence of psychosocial guidance and counselling services (GCS) on secondary school students' academic performance in Tanga City. The study employed a mixed method approach that utilized a correlation and a case study design. The study's sample size was 423 respondents, including 330 students, 26 heads of schools, 33 guidance counsellors, 33 academic teachers and one City Educational Officer. The study used questionnaires with close and open - ended questions and semi structured interview guides for data collection. Data was analyzed thematically and through the descriptive statistics as well through the hypothesis testing. The study concludes that the academic performance of the students is good; psychosocial GCS have assisted them in providing helpful instruction on psychological and social issues which otherwise would interfere with their academic performance. Furthermore, there is a significant positive relationship between students' access to psychosocial GCS and their academic performance. The study recommends the establishment of a strong school GCS policy which will oversee the effective implementation of the psychosocial GCS in the schools. It also recommends the employment of supervisory personnel trained in guidance and counselling psychology, who would oversee the assessment of the problems and needs of students. Finally, the study recommends the training of the guidance and counsellor teachers in the field of school guidance and counselling psychology in order to equip them with professionalism for rendering quality services.
\end{abstract}

Keywords: Guidance, Counselling, Psychosocial Guidance and counselling services (GCS), performance

\section{Introduction}

Psychosocial Guidance and Counselling Services (GCS) is one of the major components of school guidance and counselling program. The services assist students in cultivating their self-esteem, selfconcept and self-image, providing them with helpful instructions on psychological and social issues which would otherwise interfere with their academic performance. The services also assist students in gaining stress management skills for their wellbeing. They also help them in reducing anxiety and inspire them to be focused on their studies. Furthermore, the services motivate them to observe self-care as essential for their psychological wellbeing and stir them in developing interest in their daily school activities. Psychosocial GCS also assist the students in reducing fears and doubts concerning relationships and academic performances, inspiring them to honor and respect their educational pursuit. They furthermore assist students in their personal development and growth, enabling them to reach their full potential (Biswlo, 1996; Naik, 2004; Mwamwenda, 2004; Mutie \& Ndambuki, 2005).

Bruce and Cockreham (2004) have noted that students face a number of problems during adolescence which may affect their readiness to learn. In most cases, they face problems that are not dealt with accordingly and therefore frustrations and developmental difficulties surface and affect their wellbeing, which in turn may affect their academic performance. In highlighting these problems, Thompson (2002) points out those psychosocial issues like substance abuse, alienation, victimization, family dysfunction, violence, truancy, sexual harassments, suicide rates, and 
underachievement and school dropouts are some of the problems which affect children in their learning endeavor. All these result in significant psychological and economic problems to students. These problems have led many nations to introduce school guidance and counselling in their education systems in order to help the students to harmonize the learning pursuit with their wellbeing. The difference between guidance and counselling is that guidance services are aimed at helping students' whole person - development while counselling is targeted at helping students with problems. In other words guidance is preventive and developmental in nature whereas counselling is more of supportive, remedial work (Lai-Yeung, 2014).

The academic performance in most secondary schools in Tanzania has been declining due to indiscipline in the schools (URT, 2014). According to Koomson et al., (2005), school discipline aims at ensuring a safe and happy learning environment that enhances academic performance. Various studies have shown that despite the government efforts to implement guidance and counselling in schools and colleges in Tanzania, disciplinary problems in the country have been increasing over time (Sima \& Mkumbo, 2005, 2006; Sima, 2010). One example is the case reported by the Mwananchi Newspaper of $5^{\text {th }}$ December, 2012 that students of Ruaruke Secondary School in Rufiji District had sexually harassed female teachers using knives and humiliated them through caricature drawings and setting teachers' houses on fire.

It was also reported that students of Makumbusho Secondary School in Kinondoni District in Dar es Salaam smoked marijuana openly and played gambling games in their class rooms (Majira Newspaper, $8^{\text {th }}$ October 2012). Etsey (2005) argues that indiscipline cases in schools should be dealt with strategically; otherwise there would be poor concentration to studies that may lead to poor academic performance. Stanley (2014) also supports this fact by affirming that the management of school discipline has an impact on students' academic performance.

According to URT (2014), the quality of education in Tanzania has deteriorated in the last few years as the focus of the government is on inputs more than outputs and outcomes. In 2012, less than half, $43.1 \%$ of all the students who sat for the Certificate of Secondary Education Examination (CSEE) passed the examinations (URT, 2013). The report emphasized that both national examinations and independent assessments show poor learning outcomes.

Several programs have been implemented in the country's education system to improve students' academic performance e.g. Secondary Education Development Program (SEDP 1) that aimed at improving quality education by increasing the pass rate for division I to III from $36 \%$ in 2004 to $70 \%$ in 2009 (URT, 2013). However, URT (2012) reported that academic performance had been deteriorating. At the national level, the pass rate trend for division I to III was as follows: $36.6 \%$ in $2007,31 \%$ in 2008 , $17.91 \%$ in 2009, 11.59\% in 2010 and $10.05 \%$ in 2011.

It was also reported in the same year that the best five regions were Kilimanjaro (16.64\%), Dar es Salaam (11.97\%), Mbeya (12.04\%), Coast (11.92\%) and Arusha (11.90\%) respectively. The last five regions from the bottom in ascending order were Lindi (4.41\%), Mtwara (4.99\%), Tanga (5.45\%), Singida (6.31\%) and Rukwa (6.95\%).

Further improvement of academic performance resulted to the Big Results Now (BRN) which strategized to increase the Certificate of Secondary school Education Examination (CSEE) pass rates to $60 \%$ by $2013,70 \%$ by 2014 and to more than $80 \%$ by 2015 (URT, 2013). However, according to URT (2014) the secondary school students' academic performance in the country has been declining from time to time.

A similar study by Atsuwe and Albert (2018) which sought to establish the influence of guidance and counselling program on the academic performance of secondary school students in Makurdi Local Government Area of Benue State in Nigeria found that guidance and counselling program in schools has a positive impact on students' academic performance. Another study by Ndirangu (2007) which sought to establish the influence of guidance and counselling program on academic performance of selected public secondary school students in Bahati Division of Nakuru District in Kenya found that guidance and counselling program has a positive impact on students' academic performance. This necessitated the need to conduct a study to find out whether guidance and counselling program in Tanzanian secondary schools has any influence in the academic performance of secondary school students.

The declining of the secondary school students' academic performance has a negative reflection on the various programs (eg. The BRN and the SEDP) 
put in place by the government to promote academic performance in the country. Few concerns have focused on guidance and counselling program as an important initiative in enhancing academic performance. While the government has put efforts in implementing guidance and counselling program in schools, a number of studies for example, The challenges in Provision of counselling Services in Secondary schools in Tanzania by Sima (2010), GCS in Tanzania Schools: The calibre of personnel and constants by Kano (2012) and The Evaluation of the Implementation of GCS in Tabora Municipality, Tanzania by Mushi and Malusu (2017) indicate that guidance and counselling program in schools may not have achieved its objectives as students still lack the competencies required to optimize their academic performance. A survey that sought to find out why there was a persistent poor academic performance by secondary school students in Tanga Region, which was conducted by the Association of Heads of secondary schools in the region (TAHOSSA, 2011) identified truancy as one among a number of factors that contributed to a persistent poor academic performance by secondary school students in Tanga region.

Omari (2006) argues that children have their dreams, objectives and aspirations and that, they have plans and ideas on how to achieve their goals. He further asserts that though some of their ideas may be potentially good, they may lack proper ways to achieve them due to inexperience and lack of guidance. On the contrary, he records that the same ideas and aspirations may cause some social problems if they are misused, ("Indeed that is one way from which delinquents are produced in the society"). He finally affirms the necessity of guiding students as they struggle to achieve their goals. Braddock (2001) also argues that the purpose of guidance and counselling in schools is to decrease disciplinary problems among students, foster positive study attitudes and habits and improve academic performance. Likewise, when GCS are offered comprehensively, that is, including the major components namely educational, career and psychosocial components, there are less personal problems among students in the schools and students become well-disciplined with improved academic performance (Mikaye, 2012).

Considering all the efforts placed by the government for the purpose of improving students' academic performance and the little information which was available on the extent to which GCS have been used to assist students' in raising their academic performance, this study sought to provide some insights into these issues and establish a relationship between psychosocial GCS and students' academic performance. The study was guided by the following five questions:

1. What is the students' attitude towards the role of psychosocial GCS on academic performance?

2. What is the general perception on students' academic performance by the academic teachers, guidance counsellors and students themselves?

3. What is the relationship between the level of effectiveness of psychosocial GCS and students' academic performance?

4. What is the attitude of academic teachers and guidance counsellors toward psychosocial GCS?

5. What is the perception of heads of schools regarding the role of psychosocial GCS?

\section{Theoretical underpinnings}

This study was underpinned by the Social Learning model. This model assumes the principles of the Social Learning Theory developed by Albert Bandura (1980). The model emphasizes that behavior is learned through social interaction in the form of observation and imitation of what others are doing around you, including the significant others. The theory describes maladjusted behaviors as behaviors learnt through the complex process of socialization. Omulema (2000) advocated that human behavior can be modified using learning principles to change behavior. Regarding this study, teacher counsellors can use behavioral techniques like self-directed behavior which may deal with learning, studying and time management skills in schools to foster students' academic performance.

In supporting the theory, Zimmerman (2000) found that there is a need for the study of improvement in self-regulation for learning because lack of selfregulation strategies in learning leads to poor learning processes and consequently poor performance. This is important, especially to secondary school students in their pursuit of selfdirected behaviors as individuals, to regulate their learning, studying and self-management skills for quality performance. Concurrently, Mutie and Ndambuki (2004) found that learning is internalized when the learner is actively involved and that 
learning to study the correct way improves academic results.

The Social Learning Model used in this study provides grounds for the guidance counsellor teachers to apply its principles to help students modify maladjusted behaviors and participate in self-regulation strategies in learning which may lead them to excellent learning processes and boost their academic performance.

\section{Empirical Literature}

Some practical studies relevant to this study have been done at the international level, in Africa and particularly in Tanzania. This section therefore gives a summary of some empirical studies supporting the value of guidance and counselling in schools. It also includes studies done on the implementation of guidance and counselling circulars, policies and mission statements in the education systems of various nations:

A study in Rhode Island which explored relationships among school counselling practices, secondary school demographics and student outcomes during a 2-year period, showed that there was strong and consistent correlations between increased amounts of school counselling services and positive student outcome (Carey, Dimmitt \& Wilkerson, 2012).

In Kenya, Ndirangu (2007) established that secondary schools in the study area differed in the number of GCS that they had implemented. The findings also indicated that guidance and counselling program had a positive impact on students' academic performance.

Njoka (2014) in his study in Kenya also indicated that inorder for students to benefit from their learning and realise academic success, effective support through professional guidance and counselling founded on sound understanding and application of counselling theories is of critical importance.

Mwamwenda (2004) conducted a study which affirms that people with positive self-concepts are better adjusted and perform better at school than people with negative self - concept. The study conceptualized that all secondary schools in the country have established GCS in accordance with the government circular number 11 of 2002. The circular mandatorily instructed all schools and teachers' colleges to establish these services.

Although most African countries recognize the important role of organized guidance and counselling programs, there are inadequate studies which assessed the effectiveness of the programmed services being implemented so as to improve the students' decision making processes that will lead to beneficial improvements in the future (Folkman \& Moskowit, 2004). Therefore, this study sought to establish the Influence of psychosocial Guidance and Counselling Services on Secondary School Students' Academic Performance among the secondary schools in Tanga City.

\section{Research Methodology}

The study employed a mixed method approach that utilized a correlation and a case study design. The study was conducted in Tanga City, Tanzania. This study area was chosen as a research site due to the available evidence of poor performance among students in the national examinations, specifically the pass rate report in form four examinations by division in the years 2001-2013 (URT, 2014). The report showed that Tanga Region was one of the last five regions which had poorly performed in the Form Four Certificate of Secondary Education Examinations.

The researcher sought to establish how the academic performance may have or may not have been influenced by psychosocial GCS in the schools under study. The sampling procedure for this study was done first through proportional stratification followed by a random sampling technique since the study embraced both government and nongovernment secondary schools from Tanga City (Leedy \& Ormrod, 2010).

According to URT (2016) Tanga City has a total of 26 government secondary schools and 17 nongovernment secondary schools which totals up to 43 secondary schools. As per Payne and Payne (2004), the appropriate sample size that matched to 43 secondary schools was 37. However, the actual number of secondary schools that participated in the study was 33. Other schools could not participate because the form four students had examinations and tests taking place during that time of data collection.

Furthermore, the number of form four students from both government and non-government secondary schools was 4783 (URT, 2016) and according to Payne and Payne (2004) the appropriate sample size for that was 356 students but the actual number of students who participated in the study was 330 . Others could not participate due to personal reasons. 
Therefore, sample size for this study comprised of 26 school heads, 33 guidance counsellors, 33 academic masters, 330 students and 1 Educational official. This amounted to 423 respondents as illustrated in Table 1:

Table 1: Composition of the Sample

\begin{tabular}{lcccccc}
\hline \multicolumn{1}{c}{ Category of Respondents } & $\begin{array}{c}\text { School } \\
\text { Heads }\end{array}$ & $\begin{array}{c}\text { GC } \\
\text { Teachers }\end{array}$ & Teacher & Students & CEOs & $\begin{array}{c}\text { Total } \\
\text { Sample }\end{array}$ \\
\hline $\begin{array}{l}\text { Government Secondary Schools } \\
\text { Non-government Secondary Schools }\end{array}$ & 15 & 19 & 19 & 190 & 243 \\
$\begin{array}{l}\text { Educational Officials } \\
\text { TOTAL }\end{array}$ & 26 & 14 & 14 & 140 & 01 & 01 \\
\hline
\end{tabular}

Data were collected from 33 secondary schools whereby in each school, the head of the school, one guidance counsellor, one academic teacher and ten form four students were involved in the exercise. However, the researcher collected data from only 26 heads of schools due to reasons beyond her control. Data was also collected from the CEO as one of the key informants based on her professional position. The semi-structured interviews consisted of a set of pre-determined items that the researcher asked the school heads and the CEO.

\section{Statistical Treatment of Data}

Data from questionnaires were processed, coded and analysed using both descriptive and inferential statistics. The descriptive statistical analysis using frequencies and percentages was used to obtain results which were presented in form of tables.

Inferential statistical analysis was done using correlation analysis to measure the degree of association between GCS and students' academic performance. In this study the researcher chose to use the students' self-assessment grades as a proxy measure of their academic performance. Ross (2006) asserts that self-assessment, when properly implemented produces valid and reliable information about student achievement. The correlation coefficient was used in testing the research question at $r=0.01$ significance level.

The study utilized thematic content approach to analyze the qualitative data gathered from semistructured interviews. Information gathered from the semi-structured interviews were further organized and grouped into themes based on the research questions.

The validity of the instrument was measured by using content validity which is a category of validity that measures the extent to which a research instrument accurately measures all aspects in a construct of interest. This was accomplished by asking experts to assess the instrument so as to determine whether they are relevant to the research problem and whether they covered adequately all the various aspects of the research problem (Ndunguru, 2007; Heale, 2015). The researcher consulted experts from the psychology department and education to seek their opinion on the questionnaire items, specifically for comprehensiveness and clarity prior to the data collection exercise. This was followed by conducting a pilot study in two of the secondary schools in Tanga City to check the reliability of the data collection instruments (Saunders, Lewis and Thorn hill, 2009).

To ensure reliability of the study instruments, the researcher adopted standardized tools that had been successfully used by other researchers in several similar studies and modified them to suit the research context. However the Cronbach's Alpha was used to evaluate the reliability of the research instrument and the obtained value of the coefficient Alpha or Cronbach's alpha was found to be 0.870 or $87 \%$. Orodho (2003) states that a Cronbach's Alpha of about 0.8 is regarded as high enough for the instrument to be assumed reliable. Therefore, in this case, the Cronbach's Alpha of 0.8 was sufficient for the reliability of the instruments. Also Triangulation was used to ensure reliability whereby quantitative and qualitative approaches were used in the study. Furthermore, the study included different groups of respondents, which also increased chances for reliability.

\section{Findings and Discussion}

The findings of the study regarding the influence of psychosocial GCS on secondary school students' academic performance in Tanga city are presented according to the five research questions which guided the study: 
Research Question 1: What is the students' attitude towards the role of psychosocial GCS on academic performance?

The findings in table 2 show that the respondents strongly agreed that psycho-social GCS assisted and helped them along the listed areas of concern. The results further show that the average point ranged from 3.71 to 4.32 . The highest average point was that the services assisted students in cultivating their self-concept, self - image and self-esteem (4.32) and the lowest average point was that the services helped them to reduce fears and doubts in relationships (3.71). The Mean (3.95) indicates the average strength of students' level of agreement on the perceived influence of accessing psycho - social GCS on their academic performance.

Table 2: Students' Attitude towards accessing Psychosocial GCS

\begin{tabular}{llcccccc}
\hline & & SD & $\mathbf{D}$ & $\mathbf{N}$ & $\mathbf{A}$ & SA \\
SN & Statements & $\mathbf{1}$ & $\mathbf{2}$ & $\mathbf{3}$ & $\mathbf{4}$ & $\mathbf{5}$ & AVP \\
\hline S1 & Help to cultivate my self-concept, self-image and self esteem & 10 & 13 & 11 & 84 & 158 & 4.32 \\
S2 & Provide instructions on psychological/social issues & 23 & 25 & 11 & 103 & 111 & 3.86 \\
S3 & Help in stress management skills for my well-being & 24 & 28 & 9 & 105 & 104 & 3.81 \\
S4 & Helpful in reducing anxiety & 15 & 18 & 16 & 118 & 107 & 3.97 \\
S5 & Motivate me to observe self-care for my well-being & 14 & 16 & 9 & 91 & 123 & 3.78 \\
S6 & Help me develop interest in my school activities & 12 & 21 & 12 & 111 & 109 & 3.75 \\
S7 & Help me reduce fears and doubts in relationships & 22 & 19 & 12 & 106 & 102 & 3.71 \\
S8 & Assist in developing social skills and inspire to work with others & 16 & 17 & 9 & 99 & 135 & 4.25 \\
S9 & Motivate me to honor and respect my educational pursuit & 18 & 17 & 6 & 114 & 116 & 4.0 \\
S10 & Assist me in growth that I may reach my full potential & 15 & 12 & 17 & 106 & 114 & 4.03 \\
& The average Strength of agreement & & & & & 3.95 \\
\hline
\end{tabular}

Research Question 2: What is the general perception on students' academic performance by the academic teachers, guidance counsellors and students themselves?

The study further sought to establish the general observation on students' academic performance by the academic teachers, guidance counsellors and the rating of the students themselves through selfassessment. Findings in Table 3 show that of all the respondents $36.3 \%$ rated students as having an average academic performance. Respondents who rated the students as having an average performance in their respective categories are academic teachers (48.5\%), guidance counsellors (45.5\%) and students themselves (33.8\%). The findings also show that of all the respondents $35.8 \%$ rated students as having a good performance. The respondents who rated the students as having a good academic performance in their respective categories are academic teachers (36.4\%), guidance counsellors (42.4\%) and students themselves (34.9\%). It can also be seen that of all the respondents $(25.3 \%)$ rated students as having a very good academic performance. The respondents who rated them as having a very good academic performance in their respective categories are academic teachers $(9.1 \%)$, guidance counsellors $(0.3 \%)$ and the students themselves (29.9\%).

It can therefore be deduced from the findings in Table 3 that more than $50 \%$ of all the respondents $(25.3 \%+35.8 \%=61.1 \%)$ rated the academic performance of the students as good and very good.

Table 3: Rating students' Academic Performance

\begin{tabular}{|c|c|c|c|c|c|c|c|c|c|c|c|}
\hline \multirow{2}{*}{$\begin{array}{c}\text { Rating academic } \\
\text { performance }\end{array}$} & \multicolumn{2}{|c|}{ Very good } & \multicolumn{2}{|c|}{ Good } & \multicolumn{2}{|c|}{ Average } & \multicolumn{2}{|c|}{ Poor } & \multicolumn{2}{|c|}{ Very poor } & \multirow[b]{2}{*}{ Total } \\
\hline & $\mathbf{F}$ & $\%$ & $\mathbf{F}$ & $\%$ & $\mathbf{F}$ & $\%$ & f & $\%$ & $\mathbf{F}$ & $\%$ & \\
\hline Academic teachers $(n=33)$ & 03 & 9.1 & 12 & & 16 & 48.5 & 02 & 6.1 & 00 & 0.0 & $33(100)$ \\
\hline Guidance counsellors ( $n=33$ ) & 01 & 03 & 14 & 42.4 & 15 & 45.5 & 02 & 6.1 & 01 & 3.0 & $33(100)$ \\
\hline Students $(n=278)$ & 83 & 29.9 & 97 & 34.9 & 94 & 33.8 & 02 & 0.7 & 02 & 0.7 & $278(100)$ \\
\hline Total & 87 & 25.3 & 123 & 35.8 & 125 & 36.3 & 06 & 1.7 & 03 & 0.9 & $344(100)$ \\
\hline
\end{tabular}


Research Question 3: What is the relationship between the level of effectiveness of psychosocial GCS and students' academic performance?

The researcher's interest was further to establish the relationship between the level of effectiveness of psychosocial GCS and the academic performance of students. In this study, the level of agreement (attitude) towards accessing psychosocial GCS was used to measure the effectiveness of the services as a proxy measure. This was based on the fact that psychosocial GCS in school settings are designed specifically for helping students achieve academically. Therefore, the level of agreement (attitude) of the students towards accessing psychosocial GCS in a way reflects the effectiveness of the services in addressing academic challenges. The researcher used the Correlation Analysis to determine the relationship between the level of agreement (attitude) of the students toward psychosocial GCS and the academic performance and whether this relationship was significant or not. Correlation was used to determine the strength and direction of the relationship between the two variables; the level of agreement (attitude) towards accessing psychosocial GCS (independent Variable) and academic performance (dependant variable). The level of agreement (attitude) toward psychosocial GCS was measured on a 5-point Likert scale (Table 2) and academic performance was measured using students' responses to a students' academic performance self-assessment question. These were run in the SPSS together with students' respective responses from the Likert scale and the results were summarized in Table 4.

Table 4: Correlation between Accessing Psychosocial Services and Academic Performance

\begin{tabular}{llll}
\hline & & Student Performance & Psycho-Social Guidance \\
\hline \multirow{2}{*}{ Student } & Pearson Correlation & 1 & $.204^{* *}$ \\
Performance & Sig. (2-tailed) & & .001 \\
& $\mathrm{~N}$ & 278 & 278 \\
\hline
\end{tabular}

** Correlation is significant at the 0.01 level (2-tailed).

Table 5: Academic Teachers' and Guidance Counsellors' Attitude towards Psychosocial GCS

\begin{tabular}{|c|c|c|c|c|c|c|c|c|c|}
\hline SN & Statements & $\begin{array}{l}\text { SD } \\
1\end{array}$ & $\begin{array}{l}\mathrm{D} \\
2\end{array}$ & $\begin{array}{l}N \\
3\end{array}$ & $\begin{array}{l}\text { A } \\
4\end{array}$ & $\begin{array}{l}\text { SA } \\
5\end{array}$ & $\mathrm{R}$ & $\mathrm{T}$ & AVP \\
\hline S1 & Help to cultivate their self-concept, self-image... & 0 & 0 & 6 & 25 & 35 & 66 & 293 & 4.44 \\
\hline S2 & Provide instruction on psychological/social issues & 0 & 0 & 4 & 33 & 29 & 66 & 289 & 4.38 \\
\hline S3 & Help in stress management skills for their well-being & 0 & 1 & 7 & 23 & 35 & 66 & 290 & 4.39 \\
\hline S4 & Helpful in reducing anxiety & 0 & 0 & 9 & 30 & 27 & 66 & 282 & 4.27 \\
\hline S5 & Motivate to observe self-care for their well-being & 0 & 0 & 6 & 29 & 31 & 66 & 289 & 4.38 \\
\hline S6 & Help them develop interest in their school activities & 0 & 1 & 8 & 29 & 29 & 67 & 287 & 4.28 \\
\hline S7 & Help them reduce fears and doubts in relationships & 0 & 0 & 9 & 26 & 30 & 65 & 281 & 4.32 \\
\hline S8 & Assist in developing social skills and inspire... & 0 & 2 & 5 & 186 & 26 & 219 & 893 & 4.08 \\
\hline S9 & Motivate them to honor their educational pursuit & 0 & 0 & 4 & 34 & 28 & 66 & 288 & 4.36 \\
\hline S10 & Assist in growth that they reach their full potential & 0 & 0 & 4 & 33 & 29 & 66 & 289 & 4.38 \\
\hline
\end{tabular}

The findings in Table 4 indicate that there is a positive and significant relationship between psychosocial GCS and students' academic performance. That is $\left(r=.204^{* *}, p<0.01\right)$. Since $p<$ 0.01 , there is a significant relationship between students' level of agreement (attitude) towards accessing psychosocial GCS and students' academic performance. This implies that the more the guidance and counselling, the better the academic performance of the students.

Research Question 4: What is the attitude of academic teachers and guidance counsellors toward psychosocial GCS?

The findings in Table 5 show that the respondents strongly agreed that psycho-social GCS assisted and helped students along the listed areas of concern. 
The results show the average point ranged from 4.08 to 4.44 . The highest average point was that the services helped students to cultivate their selfconcept, self-image and self-esteem (4.44) and the lowest average point was that the services assisted the students in developing social skills, and inspired them to work with others (4.08). The Mean of 4.30 indicates the average strength of academic masters' and guidance counsellors' level of agreement on the perceived influence of accessing psychosocial GCS on students' academic performance.

Objective 5: What is the perception of heads of schools regarding the role of psychosocial GCS?

Regarding the findings from the semi-structured interviews with the heads of schools, majority $23(88.5 \%)$ of the respondents explained that psychosocial GCS promoted students' selfawareness and helped them to cultivate their selfconcept and self-esteem which were necessary for their academic achievement. One of the heads of schools explained by saying:

Some of our students were not attending school because they assumed responsibility of taking care of their parents by doing some business which helped them earn some money to keep the family going and in this way they missed classes, but with the help of psychosocial GCS, they are brought to selfawareness and have started attending classes consistently.

The heads of schools thought that psychosocial GCS helped students in gaining stress management skills that assisted them in reducing stress which otherwise would interfere with their academic endeavors. Another head of school explained that one of his students reported that her step father, forced her to enter into sexual affairs with him, something which stressed her and interfered with her academic performance, but after the psychosocial interventions by the teacher counsellor, the student was able to calm down and continue with her studies. Some of the heads of schools emphasized on the importance of psychosocial GCS as assisting the students in providing helpful psychological instruction which helped them to deal with social issues which otherwise would interfere with their academic performance. Others reported that psychosocial GCS assisted students in developing social skills which were necessary when working with others in improving their academic performance, motivated students to observe self-care as essential for their psychological well-being.

One of the respondents added that some of the students came from families which often had conflicts and the psychosocial care which was received through the school guidance and counselling program helped students to get settled and perform well in their lessons. Another respondent gave an example of a student who wanted to leave school and remain home to take care of his mother who was often beaten by the father. He reported saying: "If it was not of the psychosocial GCS received in the school, the student would have stopped schooling. But through psychosocial GCS, he was able to remain in school and stayed focused in his studies."

Another respondent in expressing the importance of psychosocial GCS explained that one student suffered psychological problems because she was raped by her father, and was about to leave school, but with the psychosocial services which she received from the school guidance counsellor, she was able to handle the situation and pursued her studies. Still another respondent reported that the services had helped the students to be disciplined and committed to their studies. However, he emphasized that it was kind of 50/50. He reported that some students received the services and changed their behaviors while others did not take the services seriously.

Another respondent emphasized saying:

It seems that some students have very serious problems in their families to an extent that they need a professional counsellor who would deal with their problems very closely and professionally at the same time involving their parents/guardians because they know their children better. But the problem is that most of the guidance counsellors are teachers and they do not have enough time for intensive guidance and counselling because of heavy workload.

The respondent continued to emphasize with emotions how the students are suffering as if there are no parents around them.

There is moral decay all over. Children have big family problems. There are no parents at all. (Children are living in slums as if there are no parents! We need counsellors. I have 
realized that the children are not the problem! Children have problems! Some are suffering from HIV infection while others have parents/guardians who are suffering from HIV infection and many other problems.

In addition, he said,

With all these problems, students cannot be fully committed to their educational pursuit". He emphasized again with emotions saying, "So we need counsellors to bring them back to their studies. The child is being pulled in every direction, especially the girl child. This is a national problem. If we want to prevent it we should deal with the root cause of the problem and stop spraying insecticide on the leaves while the problem is in the roots.

Great emphasis had been put on in-service training but no effort is made for counsellors. Even the issue of parents neglecting their children which creates a gap between them, parents should be called to the schools and be reminded of their responsibility to exercise close parenting styles which will help children in their development and growth. I have spoken to the parents many times on the issue of parenting.

However, one of the respondents in emphasizing the benefits of having school guidance and counselling program gave an example of a form four student who had changed drastically after receiving psychosocial GCS from her guidance counsellor teacher. He reported that the student was misbehaving and her academic performance was very poor. She had several sexual partners and was performing so poorly when she was in form two. But she was at that time in form four as the best student in the class.

\section{Discussion}

The findings show that psychosocial GCS assisted students in cultivating their self-esteem, selfimage, self-concept and their self-acceptance. Schooling is a social psychological experience where risks are predicted not just on innate abilities and skills but also on the self-concepts that young people develop over time and the comparison they make to others (Marsh et al., 2005). Psycho-social GCS help students in their on-going school life, assisting them to attain psychological and social well-being which will lead them in forming good and healthy relationships with peers, teachers, parents and community members. The study has also found that psychosocial GCS assisted students in providing helpful instruction on psychological and social issues. This is supported by Gerler and Herndon (2008) who reported that psychosocial GCS helped students to cope with academic, social and other cognitive issues affecting them in and outside school.

Since schools are not in isolation, whatever happens at home, at school or in the community around affects the students psychologically and sometimes may lead to mental illness which may present itself as an abnormal behaviour. Even if the society is not speaking so much about the appropriate interventions for these problems, they know there are mental problems amidst the schools, the families and the community at large. Thompson (2002) states that suicide and sudden deaths have become a recurring crises for today's schools, requiring families, schools, and communities to help the youths. There are various events which when they happen around the students may be considered normal but in the actual sense they may affect the students psychologically. These events happen as crises and they include completed suicides, suicide threats, natural and accidental deaths, medical emergencies, terminal illnesses fires, natural disasters, and gang violence.

Taking these issues for granted, like ignoring them when they are actually there and everybody sees them is a weakness to be challenged. This calls for strong psychosocial GCS in the schools which will involve school counsellors, teachers, administrators and support personnel as well as all the stakeholders. These services are necessary for they assist students in their education pursuit. When students lack these services in their schools they end up doing mischievous things which may affect their well-being and hence fail to pursue their education successfully (Mapfumo, 2001). Accordingly, this is a great challenge in the schools because mental illness does not affect emotional health in isolation; it influences many domains of students' lives including their social interactions and educational achievements (Desocial \& Hootman, 2004). Therefore, in this case, in order to promote the best possible outcomes for students, there is a great need for early identification and treatment of mental health disorders.

There is rich evidence that when students access comprehensive psychosocial GCS in schools, they improve in school behavior, school attendance, 
academic achievement and in the level of their self esteem and attitudes toward school (Beale, 2004).

According to the research by Nkala (2014) which aimed at determining the extent at which GCS prepare secondary school students to achieve social, personal, and academic development and make informed career decisions compatible with their individual needs and abilities, the findings showed that lack of the services in the schools led to high rates of delinquency, truancy, alcohol and drug abuse and teen age pregnancies. These problems are psychological and therefore they require psychological interventions. Furthermore, studies have shown that secondary school students who suffer from mental illness are more likely to get low grades across all subjects and are retained at grade level more often than adolescents with disabilities as a whole (Wagner \& Cameto, 2004).

In their study which was done with elementary school children, Sink and Stroh (2003) found that when elementary school children attended where effective GCS were provided they performed better academically. This concurs with the study done by Wilkerson (2013) on comprehensive school counselling programmes and students achievement outcomes which compared elementary schools in Indiana with comprehensive data-driven school counselling programmes and those without and displayed higher academic outcomes compared to schools without such programs.

The findings of the study also indicated that psychosocial GCS assisted students in developing social skills and inspired them to work with others in improving their academic performance. This concurs with the study by Joy and Steen (2014) on the Achieving Success Everyday Group counselling Model: Fostering resiliency in Middle school students, who sought to discover what impact this group counselling intervention, which focused on resiliency characteristics, would have on students' academic and personal-social success. The study used both qualitative and quantitative data and the results indicated that some students achieved academically as well as in their social functions. This agrees with the study by Dimmitt and Wilkerson (2012) on comprehensive school counselling in Rhode Island: Access to services and students' outcomes who explored the relationship among school counselling practices, secondary school demographics, and student outcomes in the state of Rhode Island during a period of two years and found that there was strong and consistent correlations between increased amounts of school counselling services and positive student outcomes ranging from better attendance to a stronger sense of connection to school. Accordingly, Reback (2010) also supports the findings by observing in her study on schools' mental health services and young children's emotions, behaviour and learning that children's non-cognitive skills play a critical role in their own success and that expanding school counselling services in elementary schools is associated with improvements in students' academic performance, behaviour and mental health.

\section{Conclusion and Recommendations}

\section{Conclusion}

In conclusion, the students perceived that psychosocial GCS have assisted them in providing helpful instruction on psychological and social issues which otherwise would interfere with their academic performance. The study concludes that there is a positive relationship between the level of effectiveness of psychosocial GCS and students' academic performance.

Regarding the academic performance of the students, the academic teachers, guidance counsellors and the students themselves had a general perception that the academic performance of the students is good. The study concludes also that academic teachers and guidance counsellors perceived that the services have helped students in gaining stress management skills for their wellbeing, which is an important aspect for their academic performance. They also perceived that psycho-social GCS helped students in reducing anxiety and encouraged them to be focused in their academic achievement. The services had also motivated them to observe self-care as essential for their psychological well-being which is an important aspect in their academic performance. They also perceived that psycho-social GCS had helped students to develop interest in their daily school activities.

It is also concluded that the heads of schools and the CEO perceived that the services helped students in reducing fears and doubts concerning relationships and academic performances. The students have been assisted in developing social skills and have been inspired to work with others to improve their academic performance. The students have also been motivated to honour and respect 
their educational pursuit. They have also been assisted in their personal development and growth so as to reach their full potential, an important aspect in their academic performance.

\section{Recommendation}

The study recommends the establishment of a strong school GCS policy which will oversee the effective implementation of the psychosocial GCS in the schools. There is also a need to Employ a supervisory personnel trained in guidance and counselling who would oversee the assessment of the problems/needs of students and the running of the GCS in general.

Training of the guidance and counsellor teachers in the field of school guidance and counselling psychology is recommended in order to equip them with professionalism for rendering quality services. Finally, the school guidance and counselling programmes are recommended to be utilised by the schools in building strong relationships between the schools and students' families and between the students and their respective families by providing psychosocial education.

\section{Reference}

Atsuwe, A.B. and Albert, O.A. (2018). The influence of Guidance and Counselling on Academic performance of secondary school students in Makurdi Local Government Area, Benue State. International journal of Education studies. 05(02)2018.71-78.

Bandura, A. (1980). Gauging the relationship between self- efficacy judgement and action. Cognitive Therapy and Research.4, 263-268.

Beale, A.V.(2004).Questioning ehether you have a contemporary school counselling program. The clearing House, 78(2),73-76.

Biswalo, M.P. (1996). An Introduction to guidance and counselling in diverse African contexts: Dar es Salaam University Press.

Braddock L. (2001). Guidance programme pages. Retrieved on $19^{\text {th }}$ January $2018^{\prime}$ from http://www.fcps.com

Bruce, M.A. \& Cockreham, D. (2004). Enhancing the spiritual development of adolescent girls. Professional school counselling, 7(5).334342).

Carey J.C., Dimmitt C. \& Hatch T. (2012). Evidencebased school counselling Making a difference with data-driven practice. Thousand Oaks, CA: Corwin Press.

DeSocial, J. \& Hootman, J. (2004). Children's mental health and school success. The Journal of School Nursing 20(4): 189-196.

Dimmitt, C. \& Wilkerson B., (2012). Comprehensive School Counselling in Rhode Island. Access to Services and Students' Outcomes. Professional School Counselling 16, 125-135.

Etsey, Y.K.A. (2005). Causes of Low academic performance of primary school pupils in the Shama Sub-Metro of Shama Ahanta East Metropolitan Assembly (SAEMA) in Ghana: A Paper presented at Regional Conference on Education in West Africa, Dakar Senegal, $1^{\text {st }}$ - 2nd November, 2005.

Folkman, S., \& Moskowit, J. J. (2004). Coping: Pitfalls and Promise. The Annual Review of Psychology, 55,745-774.

Gerler, E.R. \& Herndon, E. Y. (2008). "Learning how to succeed academically in middle school." Elementary School Guidance and Counselling, 27(3), 186-197.

Heale, R., \& Twycross, A. (2015). Validity and Reliability in Quantitative Studies. Evidence Based Nurse, 18(4), 66-67.8

Joy, R. \&.Steen, S. (2014), The Achieving Success Every day Group Counselling Model: Fostering Resilience in Middle School Students. Professional School Counselling. 18(1):28-37.

Koomson, A.K, Brown, P., Dawson-Brew, E., Ahiatrogah, P.D. \& Dramanu, B.Y. (2005). Psychology of adolescence. Cape Coast: Catholic Mission Press.

Lai-Yeung, S.W.C. (2014). The need for guidance and counselling training for teachers. Procedural-social and Behavioural Sciences, 113,3643.doi:10.1016/j.sbspro.2014.01.008.

Leedy, P.D. \& Ormrod, J.E. 2010, Practical research: Planning and design (7th Ed.). Merrill Prentice Hall, Upper Saddle River, New Jersey.

Majira Newspaper (2012): Vita shuleni. Wanafunxi wamjeruhi vibaya mwalimu wao 8th October. Available at Majira hall/2012/10/vita shuleni. 
Mapfumo, J. (2001). The state of Guidance and Counselling Programmes in high Schools in Manic land, Zimbabwe, International Journal of Scientific Research in Education. ISSN: 1117-325

Marsh, H. W., Trautwein, U., Lüdtke, O., Köller, O., \& Baumert, J. (2005). Academic Self-concept, interest, grades and standardized test scores: Reciprocal effects Models of causal ordering. Child Development, 76, 397-416.

Mikaye, O.D. (2012).Influence of Guidance and counselling on Students' Discipline in Public Secondary schools in Kabondo Division, Kenya. A Masters" Research Project Report Submitted in Partial Fulfilment of Requirement of the Degree of Masters of Education in Education Administration. University of Nairobi.

Mushi J. L. and Malusu M.J. (2017).Evaluation of implementation of Guidance and Counselling services in Tabora Municipality, Tanzania. Mwenge Journal of Academic studies - Vol.5 (1)

Mutie, E. K. and Ndambuki P. (2004). Guidance and Counselling for Schools and Colleges. Nairobi: Oxford University Press.

Mwamwenda, T. S. (2004). Educational Psychology: An African perspective ( $3^{\text {rd }}$ Ed.). Heinemann Publishers, Sandton.

Naik, D. (2004). Fundamentals of guidance and counselling. Delhi: Adhyayan Publishers and Distributors.

Ndirangu, P.N. (2007) The Influence of Guidance and Counselling Programme on academic performance of selected public Secondary school students: A case of Bahati Division Nakuru District. (Masters Dissertation), Egerton University, Kenya.

Ndunguru, P.C. (2007). Research Methodology for Social Sciences. Mzumbe University.

Njoka, N.J. (2014). Theories and approaches to effective students' support in technical education in Kenya. Kenya Journal of Planning, Economics and Management. Vol.7, Issue 2.

Nkala, P. P. (2014). An assessment of the guidance and counselling programme in Secondary schools at Mzilikazi District in Bulawayo metropolitan province. IOSR Journal of Humanities and Social Science (IOSR-JHSS) Volume 19, Issue, 1Ver.III pp81-90.

Omari,I.M. (2006). Educational Psychology for Teachers. Dar es Salaam. Oxford University Press.

Omulema, B.E.E. (2000).Theory and Techniques of Counselling, Nakuru: Edgerton Schools, Government Printers.

Orodho, A.J. (2003). Essentials of Educational and Social Science Research Methods, Mazola Publishers, Nairobi.

Payne G. and Payne, G. (2004). Key Concepts in Social Research. London: Sage publications Ltd. Ross, J.A. (2006). The reliability, Validity, and Utility of self-assessment. Practical Assessment, Research and Evaluation, 11(10), 1-13

Reback, R. (2010). Schools' Mental Health Services and Young Children's Emotions, Behaviour. American Educational Research Association.

Saunders, M., Lewis, P. \& Thornhill, A. (2009). Research Methodology for business students ( $5^{\text {th }}$ Ed.). Harlow: Prentice - Hall

Sima R.G. (2010). The Challenges in the provision of counselling services in the secondary schools in Tanzania, In Paper in Education and Development (PED) No. 29 pp113-133

Sima R.G. \& Mkumbo K. (2005). A study on Analysis of counselling services in secondary schools (Research Report to UDSM - NORAD)

Sink, C.A. \& Stroh H.R., (2003). Raising Achievement Test Scores of Early Elementary School Students Through Comprehensive School Counselling Programs. Professional School Counselling, 6(5), 350-364.

Stanley, S. (2014). International Journal of Academic Research in Progressive Education and Development 2014, Vol.3, No.1 ISSN: 2226 634.

TAHOSSA, (2011). A Survey that sought to find out why there was a persistent poor academic performance by secondary school students in Tanga region: Available at http://repository.out.ac.tz Edina, Isabella Joseph_September_13th_2013. 
Thompson, A. R. (2002). School Counselling, the Best Practices for Working in the Schools $12^{\text {nd }}$ Ed).Great Britain: Brunner - Rutledge.

URT (2013). Basic Education Statistics. The United Republic of Tanzania.

URT (2016). Basic Education Statistics. The United Republic of Tanzania.

URT (2014). Economic and Social Research Foundation. The united Republic of Tanzania

URT(2012). National Examination Council of Tanzania, CSEE, 2012. Examination Results.

URT. (2002). Waraka wa Elimu namba 11 wa Mwaka 2002: Kuanzisha Huduma za Malezi na Ushauri Nasaha kwa Wanafunzi Katika Shule na Vyuo Vya Ualimu. Dar es Salaam: Ministry of Education and Culture.

Wagner, M. \& Cameto, R. (2004). The Characteristics, Experiences, and Outcomes of Youth with Emotional Disturbances. A Report from the National Longitudinal Transition Study-2 3(2):1-7.

Wilkerson, K. Perusse R., \& Hughes, A. (2013). Compressive School Counselling versus nonRAMP Schools. Professional School Counselling, 16(3), 172-184.

Zimmerman, B.J. (2000). Attaining self-regulation: Asocial cognitive perspective. In $\mathrm{M}$. Boekkerts, P.R.Pintrich, \&M. Zeidner (Eds), Handbook of self- Regulation (pp.13-39).San Diego, CA, US: Academic press. 